\title{
Facing EL teachers' burnout through motivation
}

\author{
Giuseppe Caruso \\ University of Jyväskylä EIstituto di Istruzione Superiore "R. Cartesio", Finland E Italy
}

\begin{tabular}{|c|c|}
\hline Article Info & Abstract \\
\hline $\begin{array}{l}\text { Article History } \\
\text { Submitted: } 4 \text { July } 2018 \\
\text { Revised: 12 February } 2019 \\
\text { Published online: } 1 \text { April } 2019\end{array}$ & \multirow{2}{*}{$\begin{array}{l}\text { The educational institutions in many countries are faced with the major problem } \\
\text { of teacher burnout causing high rates of attrition and absenteeism. There is } \\
\text { widespread agreement among researchers that teacher burnout can effectively } \\
\text { be countered through emphasis on teacher motivation. The Author, an English } \\
\text { language teacher, carried out a 2-year qualitative research focusing on how to } \\
\text { cope with potential burnout conditions. As shown in this article, the Author } \\
\text { experienced personally how teacher burnout can be prevented through a } \\
\text { mutually reinforcing cycle of teacher and student motivation activated by the } \\
\text { implementation of a Postmethod emotion-focused pedagogical framework. In } \\
\text { this picture the emphasis on the quality of life in the English classroom proved } \\
\text { essential. }\end{array}$} \\
\hline $\begin{array}{l}\text { Keywords } \\
\text { Teacher burnout } \\
\text { Teacher motivation } \\
\text { Emotion-focused pedagogy } \\
\text { ELT } \\
\text { Postmethod }\end{array}$ & \\
\hline
\end{tabular}

\section{Introduction}

This article is about a two-year collaboration project involving the Language Department of the University of Jyväskylä and the "R. Cartesio" Upper Secondary School of Olevano Romano, a town $60 \mathrm{~km}$ east of Rome. The project, which started in September 2014 and ended in July 2016, concerned a qualitative case study focused on my experience as a teacher tackling conditions which were very likely to cause burnout. I successfully faced those conditions by creating a teacher-student rapport depending on the emphasis on the quality of life in the classroom.

What makes this research relevant is that it deals with an important issue facing educational institutions in many countries, teacher burnout, which is a major cause of both teacher absenteeism, that is frequent absence from work, (Brown \& Arnell, 2012; Jacobson, 2016; KippsVaughan, 2013; Lee et al., 2015) and of teacher attrition, that is the early resignation (Brown \& Roloff, 2011; Buchanan et al., 2013; Kraeger \& Walker, 1992; Manno, 2016; Vanderberghe \& Huberman, 1999).

I will first provide the context for my research by giving some general information about burnout and its consequences, and by discussing the role of motivation in preventing teacher burnout. Then I will state the scope and the purpose of my study.

\subsection{Burnout}

The term burnout was first used by the psychologist Freudenberger, who saw it as "a feeling of exhaustion and fatigue" (1974, p. 160) of the staff of the crisis intervention institutions (1974, p.

\footnotetext{
Address of Corresponding Author

Giuseppe Caruso, Language Department, University of Jyväskylä, Finland Istituto di Istruzione Superiore "R. Cartesio", Olevano Romano, Italy.

$\triangle$ gius.vir@libero.it

0000-0001-5126-3917

How to cite: Caruso, G. (2019). Facing EL teachers' burnout through motivation. Journal of Pedagogical Research, 3(1), 1-14. doi: $10.33902 /$ JPR.2019.0
} 
159). Maslach (1982) developed Freudenberger's views, and defined burnout a syndrome of "emotional exhaustion, depersonalization and reduced personal accomplishment". In the following decades, the overwhelming majority of researchers related burnout to stress, e. g. Betoret (2006) and Brown and Roloff (2011).

\subsection{The consequences of teacher burnout}

Teacher burnout is a major issue facing educational institutions in many countries, being related to both teacher absenteeism, that is teachers' frequent or habitual absence from work, (Brown \& Arnell, 2012; Jacobson, 2016; Kipps-Vaughan, 2013; Lee et al., 2015) and of teacher attrition, that is the resignation from profession (Brown \& Roloff, 2011; Buchanan et al., 2013; Kraeger \& Walker, 1992; Manno, 2016; Vanderberghe \& Huberman, 1999). I will now look deeper into absenteeism and attrition by taking into account the situation in three important countries: USA, Italy and England.

\subsubsection{Absenteeism}

In the USA, according to the figures issued by the Department of Education, in 2016, 27\% of teachers were absent more than 10 school days for reasons unrelated to school activities (US DoE, 2016). Concerning Italy, there are no data available after the school year 2011-2012, for which the Ministry of Education produced the official figure of 7.9 absence days per teacher because of sickness (Ministero Pubblica Istruzione, 2012). In fact, by dividing the total number of days teachers were absent, 6,194,402, (Ministero Pubblica Istruzione, 2012) by the total number of teachers in Italian public schools in the same school year, 625,878 (ISTAT 2013, p.14), the actual figure is 9.9 absence days per teacher, which seems to be the same as the figure of the USA, but, at a closer scrutiny, it is higher, because the USA figure only regards one fourth of the teacher workforce. As far as England is concerned, this official statement by the Department for Education and the Institute of Education of the University of London (2014) gives an idea of the seriousness of the issue: "Unjustified absenteeism by teachers is higher than in many other countries".

\subsubsection{Attrition}

Concerning teacher attrition in the USA, it is to be noted that it was 8\% in 2011-12 (Goldring, 2014), resulting into a percentage between 40 and 50 in the first 5 years of teachers' career (Di Carlo, 2011; Ingersoll, 2015). In Italy, attrition concerned 24\% of teacher workforce from 2000 until 2008 (Fondazione Giovanni Agnelli, 2008), after 2008 there are no official data available. In England in 2015, 10\% of teachers left the profession (DfE, 2016), resulting into a quarter of the teacher workforce in three years (Scott, 2016). High rates of teacher attrition affect the quality of teaching and involve high financial costs. As far as the USA is concerned, according to a report released by the Alliance for Excellent Education (2014), it costs up to $\$ 2.2$ billion every year.

\subsection{Teacher burnout and teacher motivation}

Both absenteeism and attrition can be prevented by removing their cause, burnout, which may be considered from a psychological or a sociological point of view (Dworkin, 2001), with the cure varying accordingly. In the psychological approach, treatment aims at helping burned out individuals learn how to cope with stressors. In the sociological approach, burnout is supposed to be caused by organizational factors and cannot be tackled through individual action, but by changing these factors. On the basis of a psychological approach, Nagel and Brown (2003) argued that effective stress management may reduce teacher burnout, and they suggested exercise, meditation, diaphragmatic breathing and social contacts. In a sociological perspective, teacher burnout is thought to be effectively dealt with through structural changes in schools (Dworkin, 2001). Beer and Beer (1992) argued that since individuals with high self-esteem are more assertive in meeting environmental demands, educational organizations should set as their goal the development of procedures for supporting teachers. For Brown and Roloff too (2011), an organizational environment where workers perceive being valued and supported can prove 
useful. In this respect, it would be worth mentioning Betoret (2006), who maintained that teachers perceiving the support from schools are more motivated and less affected by occupational stressors and, as a consequence, report less burnout. And, as was highlighted by Cox (2017) and Rosenow (2005), teacher motivation can play an important role in preventing burnout. Rosenow (2005), in particular, argued that teacher motivation is the most effective solution to the problems of stress, burnout and depression. Another researcher who related teacher motivation to the prevention of burnout is Roberts (2014). These views are developed by the present study, which deals with the role of teacher motivation in preventing burnout, focusing on English language teaching.

\subsection{The present study}

The purpose of this article, giving an account of a teacher's successful experience in preventing burnout, is not to provide a model to be mechanically applied in every circumstance, but to offer material for reflection to educators in their effort to design context sensitive strategies to face burnout.

If resilience is important in enabling teachers to cope with stressors potentially leading to burnout, teacher motivation is much more important, since it enhances resilience itself. If teachers go to school because they feel they have to, and are strong enough, they might cope with all possible stressors. But teachers' life and work would be much easier and much more pleasant if they were motivated and eager to go to school because they want to try the new materials they have created, or they cannot wait to sing with the students or tell them new jokes. In this article, I focus on my own professional experience, as an English language teacher witnessing the decisive role of motivation in letting me successfully face stressors which were likely to cause burnout.

I resumed teaching in September 2014, after a ten-year absence from school, during which I worked as a lecturer in Italian at the University of Jyväskylä, where I also pursued a PhD in the pedagogy of foreign languages (Caruso, 2015). After 10 years I was an older man, and was faced with students whose culture was different from the ones' I had left ten years earlier. Furthermore, I was far from my family, who lived abroad, and, in order to see them, I had to bear the fatigue of frequent and long journeys. Lastly, after an interesting and rewarding experience of academic teaching and research, at school I was faced with an obsolete and inefficient system which seemed to be unaffected by the changes in society and culture. In these conditions, the risk which I was likely to incur was burnout and consequent absenteeism, in the form of long sick leaves, which could have been a loophole, if the situation had proved unbearable.

To better face stress, I asked for a part-time job, I regularly took food supplements, sought social contacts, and tried to rest as much as possible. Also planning a long leave after two years proved psychologically useful. All this enhanced my resilience, but resilience without a strong professional motivation would not have been enough to skip the temptation of absenteeism. With this awareness I did actively pursue my own motivation directly and indirectly.

The direct pursuit of motivation occurred in two ways: through this project, which provided me with a purpose, and also by means of an emotional involvement in my job through the creation of my own teaching materials on a sustainable basis. By sustainable I mean without any extra burden, as suggested by Allwright, according to whom, in the classroom it is necessary to "minimize the extra effort of all sorts for all concerned" (2005). It is to be noted that Allwright clearly related sustainability to a strategy meant to prevent burnout. According to him "learners and teachers work together in a way that does not lead to burnout, but that is indefinitely sustainable" (2003, pp.127-128). I also pursued motivation indirectly, by aiming at motivating students, in the belief that motivated students enhance teachers' motivation, in a mutually reinforcing cycle, as was discussed by Bernaus and Gardner (2009) and Skinner and Belmont (1993). 


\section{Method}

\subsection{Participants}

4 classes from the language line of the Upper Secondary School of Olevano Romano were involved in this research, two of them for 2 consecutive years: 4C 2014-2015 (22 students), later 5C 2015-2016 (21 students); 3C 2014-2015 (24 students), later 4C 2015-2016 (24 students); 5C 2014-2015 (22 students); 3C 2015-2016 (27 students). The Table 1 synthesizes these data.

Table 1.

Participants

\begin{tabular}{ccc}
\hline Groups & Classes & Number of students \\
\hline \multirow{2}{*}{1} & 4C 2014-15 & 22 \\
& 5C 2015-16 & 21 \\
\hline \multirow{2}{*}{2} & 3C 2014-15 & 24 \\
& 4C 2015-16 & 24 \\
\hline 3 & 5C 2014-15 & 22 \\
\hline 4 & 3C 2015-16
\end{tabular}

Note: Groups 1 and 2 include the students of the two classes followed for 2 consecutive years

\subsection{Data collection tools and data analysis}

When dealing with teacher stress and burnout, there are researchers who follow a quantitative approach using such investigative tools as the Maslach Burnout Inventory (Maslach \& Jackson, 1981) and the Dworkin Teacher Burnout Scale, also known as the Alienational Burnout Scale (Dworkin 1987, 2000). However, the psychometric approach was questioned by Brown and Ralph (1994: 5), because, in their opinion, it is impossible to reach objectivity in measuring stress. Consequently, they advocated the alternative approach of "illuminative research", derived from Parlett's "illuminative evaluation", which is primarily concerned with interpretation rather than measurement (Parlett \& Dearden, 1977, p.13). In the "illuminative" approach, data are collected from observation, interviews and questionnaires (Brown \& Ralph, 1994, p.7).

Concerning the use of a psychometric approach, it would also be worth mentioning Browers and Tomic (2000). Although in their own research they used the Maslach Burnout Inventory, they argued that it was difficult to draw definite conclusions from the results of measurements, because of the involvement of a limited sample of teachers. Lastly, it would be useful to mention Nosek (2015), who conducted replications of 100 experimental studies published in three psychology journals. His conclusion was that only 39\% of tests replicated the original result (Nosek 2015).

This research is indebted to "illuminative evaluation" (Parlett \& Dearden, 1977, p.13 ), and it is also based on Exploratory Practice (Allwright, 2005, pp.354-355), advocating sustainable research which excludes academic investigative tools in favour of procedures from everyday classroom practice (Allwright, 1987, p.369).

I derived the conclusions of this study from the analysis of the feedback conveyed directly by the students. I also took into account parents' and fellow teachers' comments, reporting the students' views, providing their indirect feedback.

The students' direct feedback consists of comments conveyed to me verbally and their written comments, which I elicited at the end of each of the two school years, and which are the main source of data in the present study.

Written feedback was anonymous. My research required the students' real opinions, to be conveyed freely and without any pressure. If the students had sensed that it would have been possible to find out whose the comments were, their sincerity would have been affected, and their feedback would have been useless. Therefore, I did not even collect the responses myself, but asked one of the students to collect them, type them, so that I would not be able to recognize anybody's handwriting, and send them to me anonymously by e-mail. Furthermore, I asked the 
students to write in Italian, their mother tongue, since this would not provide any clues as to who wrote the comments, some students being more advanced and, consequently, more easily detectable.

As is inevitable, I made adjustments in this project while progressing. The way the students' feedback was elicited underwent some changes. At first, it was non-itemized, then I realized that it would have been more useful to suggest some guidelines, by asking the following questions: What is your opinion on the course?, What did you like best?, What didn't you like?, Which changes would you suggest?. Initially I invited the students to write their feedback at home, but quite a few of them did not write anything, therefore I decided to let them do it in the classroom. With one of the classes, 4C 2015-2016, this did not work either, since 8 students out of 24 simply ignored the request for their feedback. Consequently, I administered an anonymous multiple choice questionnaire to the whole class, with the specification that it was not compulsory. It was very quick to deal with because it had only written options to tick. I asked whether the decision not to write any feedback was due to a protest or to a lack of interest, and whether the students had a positive or negative view on the course. This time the questionnaire was filled in by everybody.

Besides the changes in the way feedback was elicited, also to be mentioned is the decision to drop the assessment of the students' proficiency. Although this was a qualitative research, at first I administered entry tests and planned final tests based on multiple choices assessing the listening and reading comprehension skills in English. I designed the tests myself, using texts which I considered suitable to the expected students' levels. The aims were: 1 . to assess the students' initial level and compare it with their final proficiency; 2 . to assess the impact of work in the classroom. The idea of measuring the progress of the students' proficiency in English, and, through it, the effectiveness of my work, was eventually dismissed, since I considered it unnecessary for the purpose of this research. As feedback was not itemized, I grouped the information into categories, producing separate tables for the course, the teacher and criticism. Before starting any discussion, a specification is necessary: given the open, and to an extent randomic, nature of the students' feedback, the analysis of the data can only provide general lines and impressions, consequently the figures are not meant to convey any precise and absolute measurements.

\subsection{Reliability}

Since the conclusions of this study were derived from the students' anonymous feedback, one might wonder what proofs can be produced regarding the reality of the data. Actually, none. Furthermore, the results of this research cannot be replicated. All the students of the classes involved in the project left the school, the last ones, 3C 2015-2016, left in July 2018. Consequently no actual proof can be provided to testify the reality of that feedback. My integrity can be checked by asking the headmaster and the teachers of my school about me, but, understandably that would not be enough, since nobody could guarantee on the reality of anonymous opinions attributed to people who are not around any more. The readers are therefore supposed to trust my word about the truthfulness of the data. But trusting me would be an act of faith, and this is not what scientific research is supposed to depend on. However, since this article is meant for teachers, I am confident they can assess whether it is reliable or not, basing their judgment on the perception deriving from their own professional experience. It is to be pointed out that the present study belongs in the line of thought rejecting the pursuit of mathematical objectivity in education and in research concerning education, which, in a Postmethod perspective are connected to each other. This line of thought opposes the mechanization of education in favour of the emphasis on the human factors in teaching. The readers who seek $100 \%$ reliable proofs will not find them here.

What is discussed in this research is not expected to be mechanically applied in every teaching context, rather, it is offered to fellow teachers as an experience to reflect on and find inspiration from in order to design their own pedagogical strategies. This makes my article useful although it cannot be qualified as proper scientific research. However, even if one argues that my paper, not 
being properly scientific, is a simple narrative, one cannot but admit it is a plausible one, and as such, it can still provide teachers with insight and inspiration. Maybe the same as would happen with two known films on teaching experiences, Dead Poets' Society with Robin Williams, and Emperor's Club, with Kevin Kline, which, although they are clearly fiction, turn out to be a source of inspiration to all teachers.

\section{Results}

As mentioned above, I availed myself of the students' indirect and direct feedback. Direct feedback in particular was verbal and written.

\subsection{Indirect feedback}

Before discussing the students' direct feedback it would be useful to give a couple of examples of what could be considered the students' indirect feedback. A mother said: "In the past, English caused my daughter anxiety, now she likes it"; a colleague said: "The students adore you! They call you the 'mythical Caruso".

\subsection{Direct verbal feedback}

Some verbal comments conveyed personally to me by single students are worth quoting: "When you are away we miss you, when the other teachers are away, for us it is a joy" (A student from 4C 2015-2016). "There are no Nobel Prizes for teaching because you won them all!" (A student from 4C 2014-2015). "With you time passes so quickly!" (A student from 5C 2015/2016). "You are the best, from an organizational and a humane point of view" (A student from 5C 2014-2015). One day in the school year 2015-2016, while I was with the class 3C, after the bell rang at the end of the lesson, a girl asked loudly: "Is it already over?". Which means that, in her opinion, the lesson had been so interesting and pleasant that she did not even notice time was passing.

\subsection{Direct written feedback}

Since the students' written feedback consisted of comments conveyed by them without any itemized pattern, I highlighted the main items myself, grouping them around three topics: the teacher, the course and critical remarks.

\subsubsection{The teacher}

As far as the teacher is concerned, the main items which emerged from the students' comments are competence, fairness and humanity/flexibility. Before proceeding with the breakdown of the data concerning the teacher, it would be useful to highlight the different tones in the way the students gave their feedback, as is shown in Table 2. Part of the students' comments (57, amounting to 46\%) deal with the course in an impersonal tone, without mentioning the teacher. Part of them (55, amounting to $45 \%)$ mention the teacher using the third person, and part (11, amounting to $9 \%$ ) address the teacher personally, using the formal "Lei" (German Sie) or even the familiar tone of the second person "tu", which is the sign of the student-teacher rapport.

One might assume that the students who mentioned me or addressed me personally in their feedback were fully aware that the way the course was organized depended on my active role and on my motivation. This is confirmed by the feedback from the school leavers C 2014-15, who, being senior students, had much experience and acquaintance with several teachers in a school characterized by a high rate of turnover because of its distance from the big city. Out of 19 students, 11 expressed appreciation for my professional qualities and 13 for my humanity and flexibility, the highest of the four groups. 
Table 2.

The tone of the students' comments

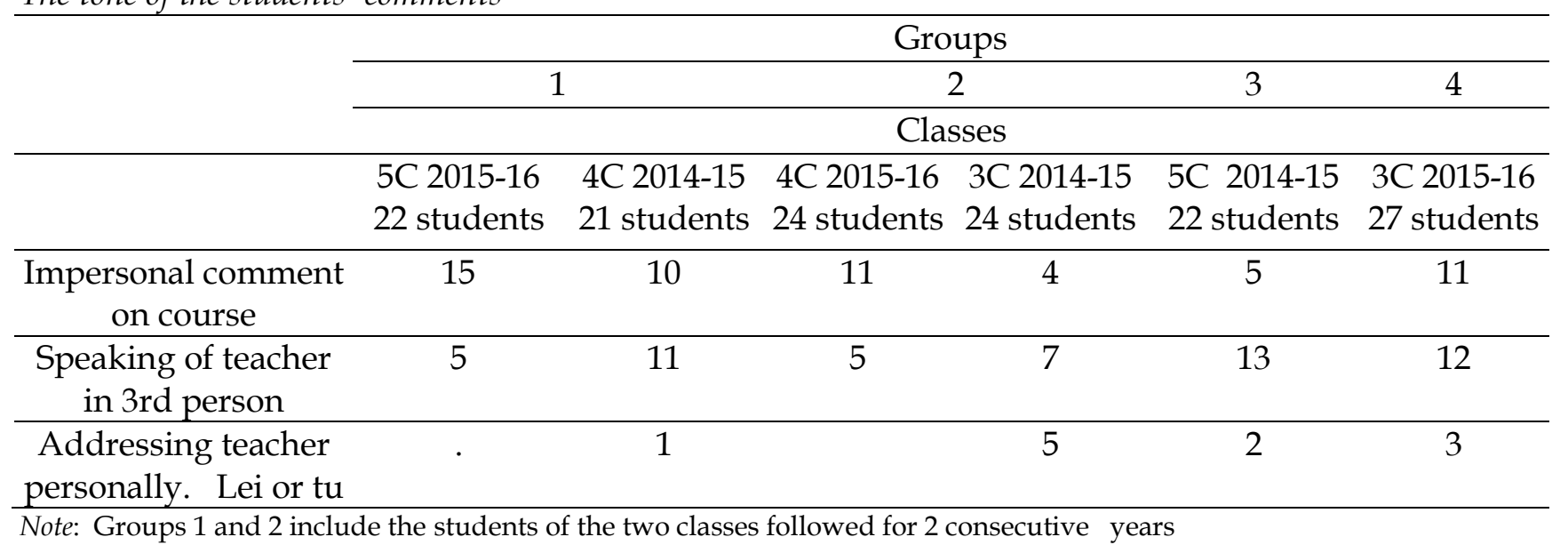

Strangely enough, in both of the classes whom I taught for two years, 4C 2014-2015/5C 20152016 and 3C 2014-2015/4C 2015-2016, at the end of the second year the figure showing a more detached tone is higher, while one would expect the opposite. The explanation might be that the students had become used to me and my pedagogy, which had lost its innovative impact and was taken for granted.

A similar process can explain why $1 / 4$ of the students from 3C 2014-15, later 4C 2015-16, conveyed their appreciation for my professional qualities the first year and none the second year. This probably means that they took those qualities for granted as the teacher-student rapport grew stronger. The same might apply to the comments of 4C 2014-15 on my human qualities, as compared to the same class a year later, when it was 5C. Each class is unique, because of different students and different group dynamics, consequently, a teacher has to be sensitive to the differences in order to plan a suitable strategy, which demands flexibility, openness and the ability to work in various directions and on varied grounds. In the present study, I tried to take into account that the students of 5C 2014-15 appreciated human understanding most, while the ones from 3C 2015-16 preferred fairness. Although both were part of the pedagogical strategy, emphasis on either was not the same in the two classes. The students' feedback concerning the teacher is shown by Table 3 .

Table 3.

The teacher's qualities most mentioned in the students' comments

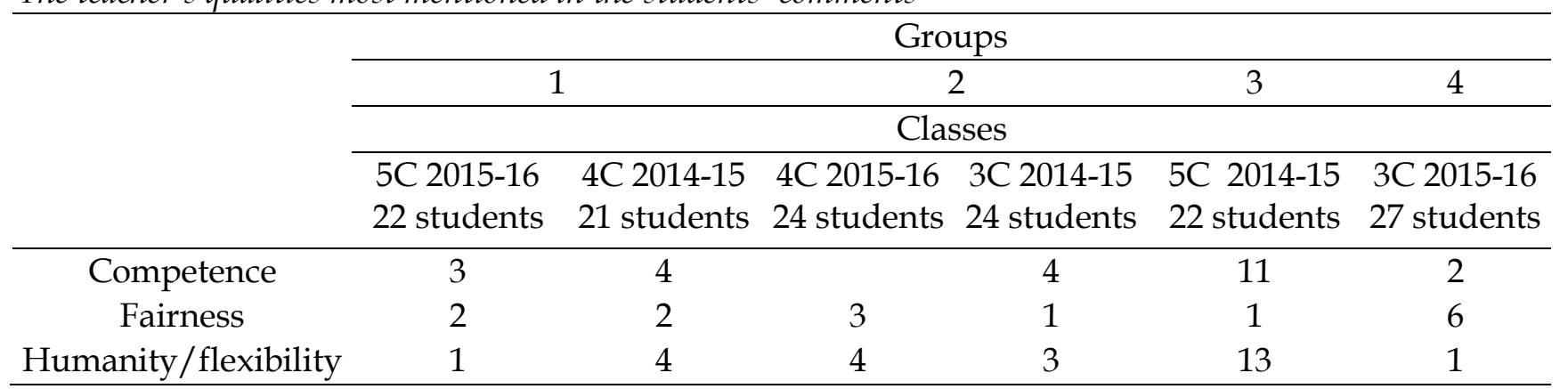

Note: Groups 1 and 2 include the students of the two classes followed for 2 consecutive years

\subsubsection{The course}

As far as the courses are concerned, the main items which emerged from the students' comments are appreciation of the course in general terms, feeling of improvement/success, effectiveness/usefulness, efficiency, fun, no pressure/no stress, interesting/not boring, involving/motivating, innovative/alternative/different/unusual method, pleasant atmosphere/ experience, teacher-student rapport, change of opinion to positive, teaching students 
responsibility, complaint about too few hours, appreciation of little emphasis on literature. The figure indicating no pressure/no stress for 4C 2014-15 (1) is low, but it is balanced by the figures describing the course as interesting/not boring (9) and involving/motivating (9). The low figures related to the effectiveness/usefulness of the course in 3C 2015-16 (2) and 5C 2014-15 (1) are balanced by other positive values, in particular, in 3C 2015-16, the feeling of improvement/success (8), and, in 5C 2014-15, the complaint about the few hours available (5). In 4C 2015-16, the highest value (12) is about the effectiveness/usefulness of the course, conveyed at the end of the second year. This figure and the figure indicating the feeling of improvement/success (1), taken together, seem to correspond to the values concerning the effectiveness/usefulness of the course (7) and the feeling of improvement/success (6) taken together in 2014-15, when the class was 3C. Probably, this is not accidental, and on this basis, one might assume a constant level of appreciation, although with changes in the distribution of the values. Even if it is low and found only in $4 \mathrm{C}$ 2015-16 (1), 5C 2014-15 (2) and 3C 2015-16 (1), it would also be worth mentioning the figure indicating the change of opinion of some students, who were perplexed at first and eventually came to appreciate the course. For $1 / 3$ of 3C 2015-16 the teacher's pedagogical line was innovative/alternative/different/unusual. It was such for almost half of 5C 2014-15, and for 1/4 of the students from 4C 2014-15, becoming 50\% of the same students the following year (5C 201516), when they were school leavers and had the chance to assess the whole two-year period. The details of the feedback regarding the course are in the Table 4.

Table 4.

The main items the students highlighted in the course

\begin{tabular}{|c|c|c|c|c|c|c|}
\hline & \multicolumn{6}{|c|}{ Groups } \\
\hline & \multirow{2}{*}{\multicolumn{2}{|c|}{1}} & \multirow{2}{*}{\multicolumn{2}{|c|}{$\begin{array}{c}2 \\
\text { Classes }\end{array}$}} & \multirow{3}{*}{$\begin{array}{c}3 \\
5 C 2014- \\
1522 \\
\text { students }\end{array}$} & \multirow[t]{2}{*}{4} \\
\hline & & & & & & \\
\hline & $\begin{array}{c}5 \mathrm{C} 2015- \\
1622 \\
\text { students }\end{array}$ & $\begin{array}{c}\text { 4C 2014- } \\
15 \quad 21 \\
\text { students }\end{array}$ & $\begin{array}{c}4 C \\
2015-16 \\
24 \\
\text { students }\end{array}$ & $\begin{array}{c}3 C \\
2014-15 \\
24 \\
\text { students }\end{array}$ & & $\begin{array}{c}3 C \\
2015-16 \\
27 \\
\text { students }\end{array}$ \\
\hline appreciation in general terms & 7 & 3 & 5 & 8 & 8 & 11 \\
\hline feeling of improvement/success & 4 & 6 & 1 & 6 & 3 & 8 \\
\hline effectiveness/usefulness & 14 & 11 & 12 & 7 & 1 & 2 \\
\hline efficiency & & 4 & & 1 & 6 & 1 \\
\hline fun & 5 & 7 & 1 & 4 & 1 & 3 \\
\hline no pressure/no stress & 7 & 1 & 4 & 2 & 3 & 4 \\
\hline interesting/not boring & 7 & 9 & 4 & 3 & 3 & 10 \\
\hline involving/motivating & 8 & 9 & 1 & 1 & & 1 \\
\hline $\begin{array}{l}\text { innovative/alternative/different/unusual } \\
\text { method }\end{array}$ & 10 & 5 & 2 & 2 & 7 & 8 \\
\hline pleasant atmosphere/experience & 2 & 1 & & 3 & 1 & 2 \\
\hline teacher-student rapport & & 2 & & 1 & & 2 \\
\hline change to positive opinion & & & 1 & & 2 & 1 \\
\hline teaching responsibility & & & & & 2 & 3 \\
\hline too few lessons & & & 2 & & 5 & 1 \\
\hline appreciation of little emphasis on liter & ature & 1 & & & 2 & \\
\hline
\end{tabular}

Note: Groups 1 and 2 include the students of the two classes followed for 2 consecutive years 


\subsubsection{Critical remarks}

The students' main complaints are as follows: little emphasis on literature, sometimes waste of time on discussions about rules in the classroom, listening comprehension as classwork, little speaking, the study of literature too bookish, superficiality of grammar explanation, shortness of oral tests, too much memorization for oral tests, the type of songs. A comparison of the positive comments and the critical remarks shows that the former outnumber the latter, which are very few. It looks as if the most critical were the youngest students, 3C 2015-2016, although their criticism did not diminish their appreciation for the teacher and the course. The only relevant critical remark seems to be the complaint about the little emphasis on literature, which peaks to $25 \%$ in 4C 2014-15 and plummets to less than 4\% in 3C 2015-16. This complaint can be explained by taking into consideration that the students were inevitably influenced by the traditional way of viewing the pedagogy of foreign languages. However, in this respect, it is to be highlighted that there were students who saw the little emphasis on literary history positively, and they were as many as the ones who wanted more of it in both 4C 2014-15 (1 student) and 5C 2014-15 (2 students). The details of the feedback concerning the students' criticism are presented in Table 5.

Table 5.

The main items in the students' critical remarks

\begin{tabular}{|c|c|c|c|c|c|c|}
\hline & \multicolumn{6}{|c|}{ Groups } \\
\hline & \multirow{2}{*}{\multicolumn{2}{|c|}{1}} & \multirow{2}{*}{\multicolumn{2}{|c|}{$\begin{array}{c}2 \\
\text { Classes }\end{array}$}} & \multirow[t]{2}{*}{3} & \multirow[t]{2}{*}{4} \\
\hline & & & & & & \\
\hline & $\begin{array}{l}5 C 2015-16 \\
22 \text { students }\end{array}$ & $\begin{array}{c}4 \mathrm{C} 2014-15 \\
21 \\
\text { students }\end{array}$ & $\begin{array}{c}4 C 2015- \\
1624 \\
\text { students }\end{array}$ & $\begin{array}{c}1524 \\
\text { students }\end{array}$ & $\begin{array}{l}5 \mathrm{C} \text { 2014-15 } \\
22 \text { students }\end{array}$ & $\begin{array}{c}3 \mathrm{C} 2015-16 \\
27 \\
\text { students }\end{array}$ \\
\hline $\begin{array}{c}\text { little emphasis on } \\
\text { literature }\end{array}$ & 3 & 1 & 3 & 4 & 2 & 1 \\
\hline $\begin{array}{l}\text { waste of time on } \\
\text { discussions }\end{array}$ & 1 & & & & 1 & 1 \\
\hline $\begin{array}{c}\text { listening comprehension } \\
\text { as classwork }\end{array}$ & . & & & & & 1 \\
\hline little English speaking & 2 & & & & & 1 \\
\hline $\begin{array}{l}\text { study of literature too } \\
\text { bookish }\end{array}$ & . & & & & & 1 \\
\hline superficiality of grammar & . & & 1 & & & 1 \\
\hline too short oral tests & . & & & & 1 & \\
\hline $\begin{array}{l}\text { too much memorization } \\
\text { for oral tests }\end{array}$ & . & & & & & 1 \\
\hline $\begin{array}{l}\text { type of songs/songs } \\
\text { chosen by teacher }\end{array}$ & . & & & 2 & & \\
\hline
\end{tabular}

Note: Groups 1 and 2 include the students of the two classes followed for 2 consecutive years

\section{Discussion}

In order to understand the reasons behind the students' positive feedback, one should take into account the general situation of Italian education. On the basis of the data provided by the most recent report issued by OECD (2017) concerning the well-being of 15-year olds in schools worldwide, I made an average calculation taking into account the indexes for anxiety (OECD, 2017) regarding Finland, as an example of a non-competitive education, Italy and two countries which are known to have extremely competitive educational systems, i. e. China (Kaiman, 2014) and South Korea (Se-Woong Koo, 2014). It turned out that the figure of Italy, where 70,8\% of students feel anxious for various aspects of school life, is almost twice as high as the figure of 
Finland, 37,2\%, which is not surprising, given the non-competitive Finnish education (OECD, 2012). What is surprising is that the figure concerning Italy is even higher than the ones concerning South Korea, $58,6 \%$ and China, $64,4 \%$. This explains the students' positive reaction to my attempt to implement a pedagogy taking into account their pace and needs.

The students appreciated these efforts, made by someone whom they saw as a motivated teacher. Their interest and motivation enhanced my emotional involvement, which increased theirs, in a mutually reinforcing cycle (Bernaus \& Gardner, 2009; Skinner \& Belmont, 1993). And this process, although it was not the only factor in the picture, proved decisive in enabling me to survive conditions which were likely to cause burnout.

\subsection{A mutually reinforcing teacher and student motivation}

In order to motivate the students, first of all, I informed them that they were involved in this research. Another important factor contributing to their motivation was the implementation of an emotional framework (Caruso, 2015) focusing on enjoyment and fun in English language teaching. The areas on which I worked were humour, songs, films and puzzle solving, an expression which, according to me, is preferable to the commonly used "problem solving" (Caruso 2015). Concerning humour, I made regular use of joke telling. Regarding puzzle solving, I exploited riddles and also information gap activities on "one-page stories". As far as songs were concerned, the students were involved in choral singing of some old songs. The students of 3C 2015-16 were very fond of The Animals Went in Two by Two, which they often sang very loudly. It might seem surprising that this and other old songs were so popular, but this probably happened because the students enjoyed the fun in the way the songs were dealt with. The students were also involved in dancing in the classroom while singing two traditional songs: Here We Go Looby Loo and Skip to My Lou.

The students were also motivated because they were impressed by the freshness of my innovations in the school work. I revolutionized testing, a major factor of school life. In traditional oral tests in English, Italian Liceo students are interviewed on memorized English literary history. Furthermore, they are always under pressure because they might be tested whenever teachers want to. It was beyond my power to do without the interviews on summarized English literary history, but I found a compromise: they lasted a couple of minutes and the students were granted a considerable amount of freedom in planning them. Since it was impossible to test everybody in the class, on testing days, the students were selected at the beginning of the lesson in a sort of ritual which met general approval because of its fairness. As far as English written tests are concerned, Italian students are traditionally expected to write a short essay in the classroom either on English literary history, reporting in writing what they memorized, or on a non-literary topic decided by the teacher. I broke this practice by having the students write a report on a "one-page story", after I read it aloud to them. The students had never done that before and found it useful and challenging.

Change also concerned the items to study for the English part of the matriculation examination. The list is traditionally based on authors from English literature and follows a chronological order. I broke this custom not only by using a thematic approach, but also by including films and songs in the list.

A useful tool I availed myself of was a small projector, one of those one can hold in one's hand, to be used with a laptop. It was not cheap, but I considered it a professional investment. Until the school year 2015-16 in the school there was only one classroom with an overhead projector, to be shared by all the classes by taking shifts, consequently the small projector available in the classroom at any time was remarkable.

Besides using innovative procedures, I also made an effort to improve the quality of life in the classroom, as suggested by Allwright (2005). With this in mind, I avoided any unnecessary anxiety and any unnecessary pressure on the students, in the belief that a relaxed atmosphere is beneficial to both teachers and learners. This involved emphasis on human understanding, for example in 
dealing with cheating, which is quite common in Italian schools. Whenever I found out that someone was cheating, I never revealed their name, but spoke to the class, saying that, although I understood the reasons behind it, I could not tolerate it, because in the long run it would harm the students themselves, by depriving them of knowledge. Consequently, I enforced no punishment, but tried to make cheating more difficult.

In preventing the students from feeling under pressure, one of the ways was a procedure which I labelled "working with Donald Duck", used in multiple choice tests designed by myself on "onepage stories" in English. On the sheets providing the options to choose, the students were allowed to write a fake name which was known to them only, e. g. Donald Duck, as one of them actually wrote. Consequently, I had no way to know whose the sheets were. The advantage in this procedure was that there was no need to cheat, and the students had the real perception of what they were really capable of.

In building a rapport with the students, I also emphasized fairness. In this respect, I negotiated with them a "contract" concerning the rules for tests. They did appreciate this, because in Italian schools, tests, especially the oral ones, are the source of frustration and anxiety, being characterized by total arbitrariness on the part of the teachers. Therefore, establishing agreed on rules in this area was definitely welcomed by the students. I also proved flexible in accepting a renegotiation of the rules, if needed. This was a real revolution. "You are doing something never seen", a mother said to me, quoting the comment of her son, a student from 4C 2014-2015.

The focus on positive emotions, through the implementation of an emotional framework in English language teaching, and the effort to improve the quality of life in the English classroom by avoiding any unnecessary pressure were very motivating for the students, whose motivation enhanced my own in a mutually reinforcing cycle.

As shown in Table 2, even the tone of most of the students' comments is testimony to a teacherstudent rapport. Only $46 \%$ of students used an impersonal and detached tone, the rest of them saw, me, the teacher, as a person close to them, to the extent that $9 \%$ addressed me personally by using "Lei" (German Sie) or even "tu" (the second singular person).

\section{Conclusion}

Although I worked for two years facing stressors which were likely to cause burnout, I was able to successfully reach the end of the second school year. Many factors may have contributed to this success, however, among them, one cannot but highlight the decisive role of the cycle of mutually reinforcing teacher and student motivation (Bernaus \& Gardner, 2009; Skinner \& Belmont, 1993), which I actively created and sustained. This happened first of all by means of an effort to improve the quality of life in the English classroom through the emphasis on humanity and fairness, by avoiding any unnecessary pressure on the students, and by negotiating rules taking into account their pace as far as the oral and written tests in English were concerned. Besides focusing on the quality of life in the classroom, I also enhanced the students' motivation, and my own, by means of the implementation of a pedagogical framework appealing to positive emotions through work on humour, puzzle-solving, singing and also dancing in the classroom. It should be added that my own motivation, besides being boosted by the students' appreciation, also depended directly on the pleasure given to me by my own personal enjoyment of the activities which were part of my pedagogical framework (Caruso, 2015). To conclude, I would like to point out that my successful experience in avoiding burnout is not meant to have any paradigmatic claim, rather, it is offered for reflection to fellow teachers facing stressors conducive to burnout, in the hope that they will find encouragement in designing their own context-sensitive strategy in teaching English, which might be motivating to both them and the learners. 


\section{References}

Alliance for Excellent Education (2014). Teacher attrition costs united states up to $\$ 2.2$ billion annually, says new alliance report. Press release 17 July 2014. Retrieved 22 March 2017 from http://all4ed.org/press/teacherattrition-costs-united-states-up-to-2-2-billion-annually-says-new-alliance-report/

Allwright, D. (1997). Quality and sustainability in teacher-research. TESOL Quarterly, 31(2), 368-370.

Allwright, R. L. (2005). Developing principles for practitioner research: The case of Exploratory Practice. The Modern Language Journal, 89(3), 353-366.

Bandura, A. (1994). Self-efficacy. In V. S. Ramachaudran (Ed.), Encyclopedia of human behavior (Vol. 4, pp. 7181). New York: Academic Press.

Beer J., \& Beer J. (1992). Burnout and stress, depression and self-esteem of teachers. Psychological Reports, 71, 1331-1336.

Bernaus M. A. W. \& Gardner R. C. (2009). Teachers' motivation, classroom strategy use, students' motivation and second language achievement. Porta Linguarum, 12, 25-36

Betoret, F. D. (2006). Stressors, self-efficacy, coping resources, and burnout among secondary school teachers in Spain. Educational Psychology, 26(4), 519-539.

Bishay A.. (1996). Teacher motivation and job satisfaction: a study employing the experience sampling method. Journal of Undergraduate Sciences, 3, 147-154

Black S. (2001). Morale matters: when teachers feel good about their work, research shows, student achievement rises. American School Board Journal, 188(1), 40-43.

Brouwers A., \& Tomic, W. (2000). W. A longitudinal study of teacher burnout and perceived self-efficacy in classroom management. Teaching and Teacher Education, 16, 239-253.

Brown S. L. \& Arnell A. T. (2012). Measuring the effect teacher absenteeism has on student achievement. International Journal of Humanities and Social Science, 2(17), 172-183.

Brown L. A. \& Roloff M. E. (2011). Extra-Role Time, Burnout, and Commitment. Business Communication Quarterly, published online 17 October 2011. Retrieved 13 March 2017 from https://web.csulb.edu/colleges/cba/aacsb/research/documents/brown.pdf

Brown, M. \& Ralph, S. (1994, April). Towards the identification and management of stress in British teachers. Paper presented at the Annual Meeting of the American Educational Research Association, New Orleans, LA.

Buchanan J., Prescott A., Schuck S., Aubusson P., Burke P., \& Louviere J. (2013). Teacher retention and attrition: views of early career teachers. Australian Journal of Teacher Education, 38(3), 112-129.

Byrne, B M. (1991). Burnout: Investigating the impact of background variables for elementary, intermediate, secondary, and university educators. Teaching and Teacher Education, 7(2), 197-209.

Caruso G. (2015). An emotional framework in foreign language pedagogy; facing the postmethod challenge. Finland: Jyväskylä University Printing House.

Cox, J. (2017). Beating teacher burnout through motivation. Retr. 10 March 2017 from http://www.teachhub.com/beating-teacher-burnout-through-motivation

Di Carlo, M. (2011). Do half of new teachers leave the profession within five years?. December 15, 2011. Retrieved 21 March 2017 from http://www.shankerinstitute.org/blog/do-half-new-teachers-leaveprofession-within-five-years

Dworkin A. G. (1987). Teacher burnout in the public schools: structural causes and consequences for children. NY: State University of New York Press.

Dworkin, A.G. (2000). Dworkin teacher burnout scale (Alienation burnout). In Lester, P.E. and L.K. Bishop (eds.). Handbook of tests and measurement in education and the social sciences (2 ${ }^{\text {nd }}$ Edition, pp. $313-314$ ). London: Scarecrow Publishers.

Dworkin A. G. (2001). Perspectives on teacher burnout and school reform. International Education Journal 2(2), 69-78.

Freudenberger H. J. (1974). Staff Burn-out. Journal of Social Issues, 30, 159-165.

Friedman, I. A. (2003). Self-Efficacy and Burnout in Teaching: The importance of interpersonal relations efficacy. Social Psychology of Education, 6, 191-215.

Goldring, R., Taie, S., \& Riddles, M. (2014). Teacher attrition and mobility: results from the 2012-13 teacher followup survey (NCES 2014-077). U.S. Department of Education. Washington, DC: National Center for Education Statistics. Retrieved 11 March 2017 from https:/ /nces.ed.gov/pubs2014/2014077.pdf. 
Indire - Istituto Nazionale Documentazione Ricerca Educativa (2010). Costruire i nuovi licei. Indicazioni $\begin{array}{llllll}\text { nazionali. } & \text { Retrieved } & 17 & \text { May } & 2017 & \text { from }\end{array}$ http://www.indire.it/lucabas/lkmw_file/licei2010///indicazioni_nuovo_impaginato/_Liceo\%20lingui stico.pdf

Ingersoll, R. M. (2003). Is there really a teacher shortage?. A research report co-sponsored by the consortium for policy. Research in Education and the Center for the Study of Teaching and Policy. Retrieved 21 March 2017 from http:/ / www.gse.upenn.edu/pdf/rmi/Shortage-RMI-09-2003.pdf

Ingersoll, R. M. (2016, April). Is there really a teacher shortage?. AERA Annual Meeting Presidential Symposia. Retrieved 21 March 2017 from http:/ / www.aera100.net/ed-talk-videos.html

Ingersoll, R. M. \& Phillips, O. (2015). Revolving door of teachers costs schools billions every year. March 30, 2015. Retrieved 21 March 2017 from http://www.npr.org/sections/ed/2015/03/30/395322012/thehidden-costs-of-teacher-turnover

ISTAT (2013). Italia in cifre. Retrieved 4 May 2017 from http://www.istat.it/it/files/2011/06/Italia_in_cifre_20132.pdf

Jacobson D. A. (2016). Causes and effects of teacher burnout. Walden University. Walden Dissertations and Doctoral Studies, Minneapolis.

Kaiman J. (2014). Nine-hour tests and lots of pressure: welcome to the Chinese school system. The Guardian 22 February 2014. $\quad$ Retrieved 92014 May https://www.theguardian.com/world/2014/feb/22/china-education-exams-parents-rebel

Kipps-Vaughan, D. (2013). Supporting teachers through stress management. The Education Digest, 79(1), 4346.

Kraeger M. M. \& Walker K. F. (1992). Attrition, burnout, job dissatisfaction and occupational therapy managers. Occupational Therapy in Health Care, 8(4), 47-62.

Lee M., Goodman C, Dandapani N. \& Kekahio W. (2015). Review of International Research on Factors Underlying Teacher Absenteeism. National Center for Education Evaluation and Regional Assistance. Institute of Education Sciences. U. S. Department of Education.

Manno M. (2016). The warning signs of teacher burnout. Retrieved 23 March 2017 from http://www.teachthought.com/pedagogy/the-warning-signs-of-teacher-burnout/

Maslach, C. (1982). Burnout: The cost of caring. Englewood Cliffs, NJ: Prentice-Hall.

Maslach, C. \& Jackson, S. E. (1981). The measurement of experienced burnout. Journal of Occupational Behavior, 2, 99-113.

Ministero Pubblica Istruzione. (2012). Assenze personale scuola. Retrieved 4 May 2017 from https://archivio.pubblica.istruzione.it/assenze_personale_scuola.shtml

Montero-Marín J., García-Campayo J., Mosquera Mera D. \& López del Hoyo Y. (2009). A new definition of burnout syndrome based on Farber's proposal. Journal of Occupational Medicine and Toxicology, 4(1), 1-17.

Nagel, L., \& Brown, S. (2003). The ABCs of managing teacher stress. The Clearing House, 76(5), 255-258.

Open Science Collaboration. (2015). Estimating the reproducibility of psychological science. Science, 349(6251), aac4716.

OECD (2012). Finland: A Non-Competitive Education for a Competitive Economy. In Strong Performers and Successful Reformers In education: Lessons from Pisa for Japan (pp. 93-111). Paris: OECD Publishing. Online at: https:// www.oecd.org/edu/school/programmeforinternationalstudentassessmentpisa/49802616.pdf

OECD (2017). PISA 2015 Results (Volume III): Students' Well-Being. Paris: OECD Publishing.

Parlett R. P., \& Dearden G. (1977). Introduction to illuminative evaluation: studies in higher education. Sacramento: Pacific Soundings Press.

Pines, A. M., \& Keinan, G. (2005). Stress and burnout: The significant difference. Personality and Individual Differences, 39(3), 625-635.

Prabhu N. S. (1990). There is no best method - why?. TESOL Quarterly, 24(2), 161-176.

Roberts R. (2014). Staying motivated and avoiding burnout as a teacher. BBC British Council May 2014. Retr. 10 March 2017 from https://www.teachingenglish.org.uk/blogs/rachael-roberts/rachael-robertsstaying-motivated-avoiding-burnout-a-teacher

Rosenow D..(2005). Stress, burnout and self-esteem among educators. Journal of Border Educational Research, $4(1), 87-92$.

Scott, S. (2016). Highest teacher leaving rate in a decade - and 6 other things we learned about the school workforce. June 30, 2016. Retrieved 21 March 2017 from http://schoolsweek.co.uk/highest-teacherleaving-rate-in-a-decade-and-6-other-things-we-learned-about-the-school-workforce/ 
Se-Woong Koo (2014). An Assault Upon Our Children, South Korea's Education System Hurts Students. New York Times 1 August 2014. Retrieved 9 May 2017 from https://www.nytimes.com/2014/08/02/opinion/sunday/south-koreas-education-system-hurtsstudents.html?src=twr\&_r=2

Skinner E. \& Belmont M. J. (1993). Motivation in the classroom. reciprocal effects of teacher behavior and student engagement across the school year. Journal of Educational Psychology, 85(4), 571-581.

Sylvia R. D. and Hutchison T. (1985). What Makes Ms. Johnson Teach? A Study of Teacher Motivation. Human Relations, 38(9), 841-856.

Vandenberghe, R., \& Huberman, A. M. (Eds.). (1999). Understanding and preventing teacher burnout: A sourcebook of international research and practice. NY: Cambridge University Press. 